\title{
Fast Accumulation of Basement Membrane Material and the Rate of Morphological Changes in Acute Experimental Diabetic Glomerular Hypertrophy
}

\author{
R. Østerby and H. J. G. Gundersen \\ Second University Clinic of Internal Medicine, Institute of Experimental Clinical Research, Institute of Pathology, \\ and Department of Cell Biology, Institute of Anatomy, Århus University, Århus, Denmark
}

Summary. Renal glomerular structures have been studied during the initial phases of renal and glomerular hypertrophy in streptozotocin diabetic rats. - After four days of diabetes significant increases were found in the following absolute structural quantities: the tuft volume $(25 \%)$, the surface area $(42 \%)$ and volume $(46 \%)$ of peripheral basement membrane, and capillary luminal volume $(29 \%)$. No further changes in these quantities took place over the succeeding 47 days. The geometry of the capillaries, however, changed over this period: at 4 days the total capillary length had increased significantly $(32 \%)$ with an unchanged average cross sectional area, whereas at 47 days the length had reverted to normal, but average cross sectional area had increased $(30 \%)$. The increased surface of filtering area may be the morphological counterpart of increased glomerular filtration rate. The changes in glomerular volume were thus accompanied by changes in glomerular structural composition which after a few weeks returned to normal, in balance with the increased volume.

Key words: Experimental diabetes, basement membrane mass, kidney hypertrophy, glomerular hypertrophy, glomerular capillaries, filtration surface, capillary morphology, stereology.

In our light microscopic study of renal growth in early experimental diabetes [1] it was shown that glomerular enlargement is demonstrable after only 4 days of streptozotocin diabetes in the rat.

Earlier studies in acute onset, juvenile diabetes have shown a similar enlargement [2] and an increase in the glomerular capillary surface [3], as well as the presence of increased amounts of glomerular capillary basement membrane (BM) material at the time of diagnosis or soon thereafter (Kroustrup, Østerby \& Gundersen, unpublished observations). The results raised the question as to whether such structural changes were due to aberrant metabolism and developed in the few weeks from the onset of metabolic derangement prior to the diagnosis of diabetes.

The purpose of the present study was to examine glomerular ultrastructure during the early glomerular enlargement in the animal model of the metabolic disturbance and, specifically, to establish whether an increase in the amount of glomerular BM material was present in the very early stages.

\section{Material and Methods}

\section{Animals}

Adult female Wistar rats weighing 240 to $270 \mathrm{~g}$ at the start of the experiment were used. Diabetes was induced by injection of streptozotocin $(55 \mathrm{mg} / \mathrm{kg}$ IP). Only animals with non-fasting blood glucose values above $300 \mathrm{mg} / 100 \mathrm{ml}$ and a weight loss below $35 \mathrm{~g}$ at termination of the study were used. The left kidney was perfusion fixed in situ at $140 \mathrm{mmHg}$ by use of $1 \%$ gluteralderhyde in modified Tyrode's buffer. The kidney was post-fixed in the perfusion medium for 90 minutes and stored in Tyrode's buffer for 1 week.

The animals used in the present study were all included in the material presented in the accompanying paper [1]. For the electron microscopic study 9 control rats (C), 9 rats with 4 days of streptozotocin diabetes (D4) and 8 rats with 47 days of streptozotocin diabetes (D47) were used.

\section{Electron Microscopy}

Tissue for electron microscopy was post-fixed in $1 \% \mathrm{OsO}_{4}$ for $1 \mathrm{~h}$, dehydrated in acetone and embedded in Vestopal W. Thin $(\sim 50 \mathrm{~nm})$ sections were stained with uranyl acetate and lead citrate. Three glomerular cross sections per animal were selected 


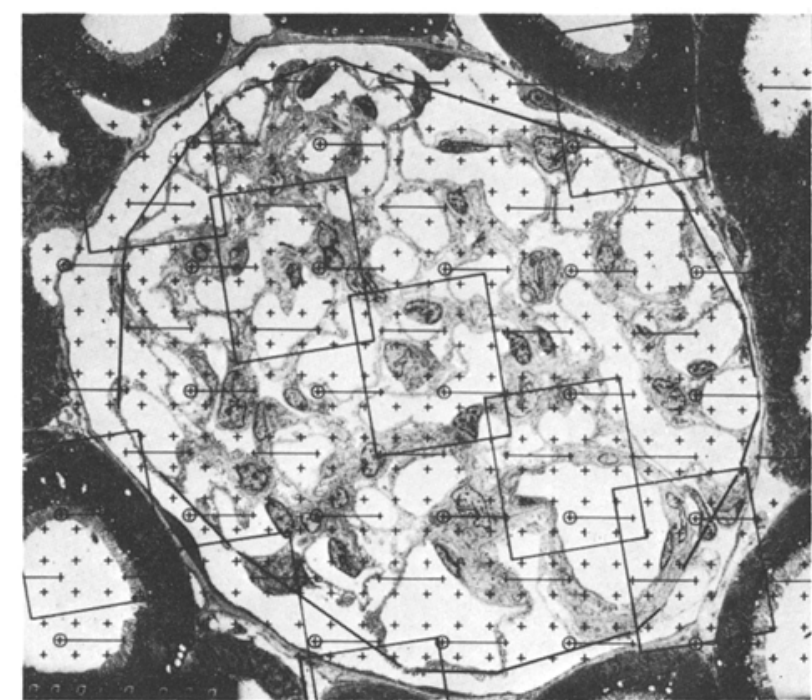

Fig. 1. Cross section of glomerular tuft obtained at Low Magnification Electron Microscopy (LMEM) with superposed point- and line-lattice used in the stereological estimations. The polygon area is delineated on the micrograph with solid lines. The rectangles are the fields photographed at high magnification, see Fig. 2. The length of a single test line was $20 \mathrm{~mm}$ corresponding to $10 \mu \mathrm{m}$

at random [4]. Each glomerular cross section was photographed in toto by Low Magnification Electron Microscopy (LMEM); final magnification was $\times 1900$. A systematic sample, comprising an average of 10 micrographs per cross section and covering $1 / 4$ of the total cross section, was photographed in a Jeol $100 \mathrm{C}$ electron microscope by High Magnification Electron Microscopy (HMEM) to provide a final magnification of $\times 11180$. For measurements of the basement membrane thickness these exposures were further enlarged to give a final magnification of $\times 33180$, using the projection unit developed by Weibel [5].

\section{Relative Structural Quantities}

A comprehensive description of most of the stereological techniques employed in this study is given by Weibel [5]. On LMEM micrographs the minimal convex figure enclosing the epithelial side of the BM was drawn, a so-called string-polygon which is illustrated in Figure 1. On the LMEM micrographs all other compartment quantities were expressed in relation to this reference space, one of them being the naked tuft volume, namely the volume delineated by the bases of epithelial foot processes (i.e. the combined volume of mesangial regions, endothelium, peripheral $\mathrm{BM}$, and capillary lumen). The naked tuft volume was in turn the reference volume employed in the quantitative analysis of the HMEM micrographs, see Figure 2. The individual tuft volume fraction was estimated by LMEM as,

$\mathrm{V}_{\mathrm{V}}$ (tuft/glomerulus $)=\frac{\sum \mathrm{P}(\text { tuft })}{\sum \mathrm{P}(\text { polygon })} \mathrm{mm}^{3} / \mathrm{mm}^{3}$

where $\Sigma P(X)$ is the total number of points hitting compartment $X$. The separate summation in numerator and denominator was carried out over the 3 glomeruli. The surface densities $\left(S_{V}\right)$ of the peripheral BM and mesangial epithelial surfaces were estimated by for example:

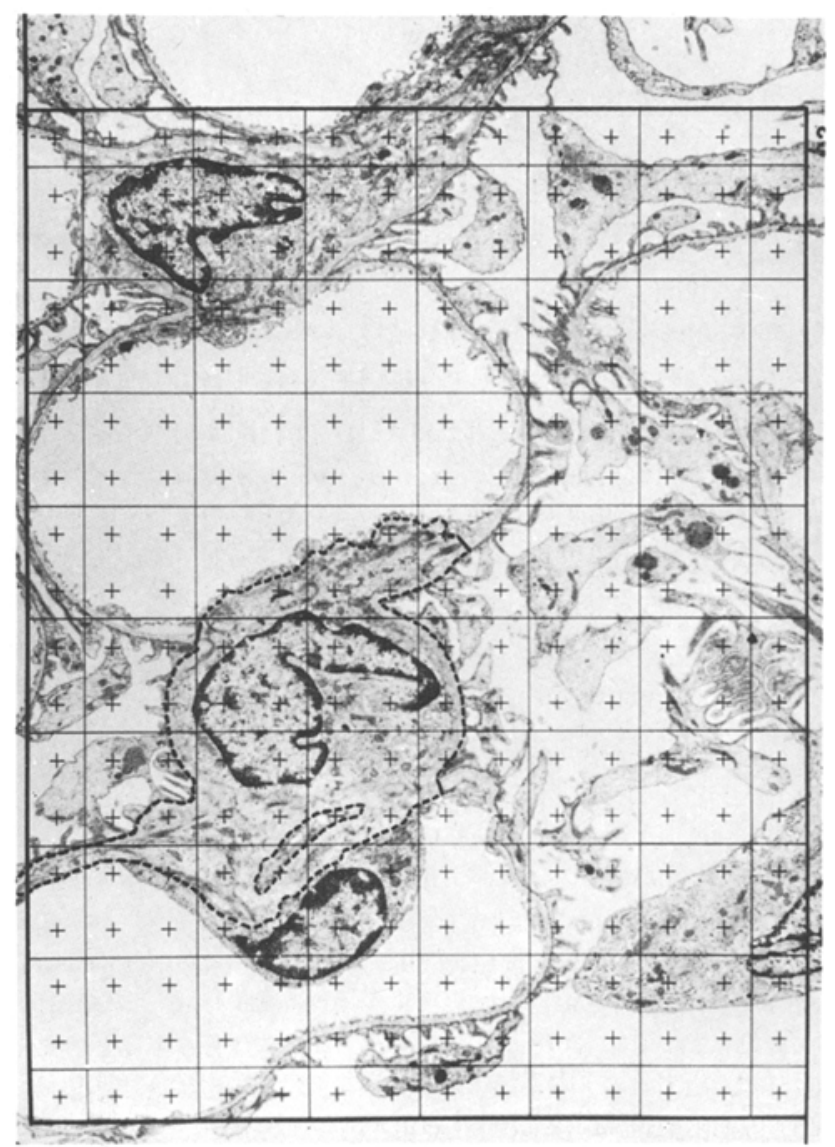

Fig. 2. High Magnification Electron Microscopy (HMEM) micrograph with grid superposed, used for estimating fractional volumes of mesangial regions (one such is delineated by stippled lines), capillary luminal space, and endothelial and epithelial cells. For these structures the coarse points of the grid (intersections of lines) were used, whereas over the peripheral basement membrane and the basement membrane-like material in the mesangial regions the fine points were counted. The distance between coarse points was $30 \mathrm{~mm}$ which corresponds to $2.7 \mu \mathrm{m}$

$$
\begin{aligned}
& \mathrm{S}_{\mathrm{V}} \text { (peripheral BM/glomerulus) } \\
& =\frac{2 \Sigma \mathrm{I} \text { (peripheral BM) }}{\mathrm{k} \cdot \Sigma \mathrm{P} \text { (polygon) }} \mathrm{mm}^{2} / \mathrm{mm}^{3}
\end{aligned}
$$

where $\Sigma I(X)$ is the total number of intersections between the surface trace of compartment $X$ and horizontal test lines (Fig. 1) and $\mathrm{k}$ is the real distance in $\mathrm{mm}$ between two adjacent test points. The length density $\left(\mathrm{L}_{\mathrm{V}}\right)$ of glomerular capillaries was estimated by:

$\mathrm{L}_{\mathrm{V}}$ (capillaries/glomerulus) $=\frac{\Sigma \mathrm{Q}(\text { lumina })}{\mathrm{k}^{2} \cdot \Sigma \mathrm{P}(\text { polygon })} \mathrm{mm} / \mathrm{mm}^{3}$

where $\Sigma Q($ lumina) is the total number of luminal profiles, some of which were separated from each other only by an endothelial 'bridge'.

On the HMEM micrographs the fractional volumes of epithelium, endothelium, capillary lumen, mesangium, peripheral $\mathrm{BM}$, and BM-like material in the mesangium were estimated by point counting with the tuft as reference volume. 


\section{Absolute Structural Quantities}

BM thickness was determined by measuring orthogonal BM intercepts (Fig. 2). The empirical distribution of orthogonal intercept length, $l_{0}$, can then be transformed into the expected distribution of true BM thickness, $t$ [6]. For the purposes reported here it suffices to notice two simple relations,

$\tilde{\mathrm{t}}_{\mathrm{h}}=\frac{8}{3 \pi} \cdot \tilde{l}_{\mathrm{o}, \mathrm{h}}$ and $\tilde{\mathrm{t}}_{\mathrm{a}}=\frac{\pi}{4} \cdot \bar{l}_{\mathrm{o}, \mathrm{a}}$

between harmonic (h) and arithmetic (a) mean thickness and the corresponding means of orthogonal intercept length.

The total volume of glomeruli per kidney, V(glom), in each animal was estimated by light microscopy in the companion study [1]. The delineation of glomerular profiles was identical at light microscopy and at LMEM (string-polygon in Figure 1). Thus, by multiplying the relative structural quantities defined above with the appropriate absolute reference volume absolute individual quantities are obtained, for example,

$\mathrm{V}($ lumen $)=\mathrm{V}_{\mathrm{V}}($ lumen/tuft $) \cdot \mathrm{V}_{\mathrm{V}}($ tuft/polygon $) \cdot \mathrm{V}($ glom $) \mathrm{mm}^{3}$

the three factors being estimated at descending magnification.

The total volume of peripheral capillary BM material was primarily estimated by,

$\mathrm{V}(\mathrm{BM})=\mathrm{S}($ peripheral $\mathrm{BM}) \cdot \overline{\mathrm{t}}_{\mathrm{a}}(\mathrm{BM}) \mathrm{mm}^{3}$

based on the relation $\bar{t}_{\mathrm{a}}=\frac{V}{\mathrm{~S}}$ defined for membranes by Weibel $\&$ Knight [7]. S denotes surface.

\section{Derived Structural Quantities}

Given the fact that the glomerular volume is enlarged by over $30 \%$ in diabetic rats [1] it is of no particular interest to look for differences in the absolute glomerular structural quantities (and a valid null hypothesis would be difficult to specify). On the other hand, differences in glomerular composition are of considerable interest. However, the elements composing the glomerulus are only directly measurable in the case of volume fractions of dimension $\mathrm{mm}^{3}$ / $\mathrm{mm}^{3}$. Even for a constant shape, all other relative structural quantities with dimensions $\mathrm{mm}^{3} / \mathrm{mm}^{3}$ change when the glomerular volume changes, as illustrated for $S_{V}$ in Figure 3. However, since the absolute quantities are known it is possible to construct estimators that have dimensions $\mathrm{mm}^{3} / \mathrm{mm}^{3}$. In stereology such estimators are known as 'shape factors' and the particular members of this family employed here are independent of the absolute reference volume. For example, $S^{3 / 2} / V=6 \cdot \sqrt{\pi} \sim 10.6$ for a sphere irrespective of its size and also therefore for an assembly of arbitrary spheres. By comparing such estimates from different groups we can test for isomorphous change of the structural quantity under consideration.

The average cross sectional area perpendicular to the capillary lumen was estimated by

$\overline{\mathrm{A}}=\frac{\mathrm{V}_{\mathrm{V}} \text { (lumen/polygon) }}{\left.\mathrm{L}_{\mathrm{V}} \text { (lumen/polygon }\right)} \mu \mathrm{m}^{2}$ the estimator being described in the companion paper [1].

Poiseuille's equation $\frac{\mathrm{p}}{\mathrm{v}}=8 \pi \cdot \eta \cdot \frac{l}{\mathrm{~A}^{2}}$ relates the geometry (length $(l)$ ) and cross sectional area (A)) of a capillary tube to function (volume flow (v) and pressure drop due to resistance (p)), via a constant of the fluid (viscosity $(\eta)$ ). Topologically, the glomerular vascular bed is a mixture of parallel and serial capillaries, and apart from reconstruction via serial sections there exists
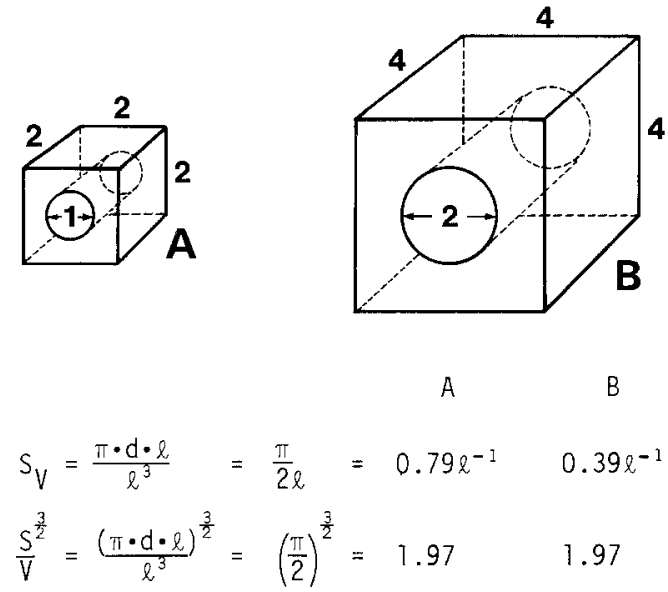

Fig. 3. Two isomorphous bodies where linear dimensions differ by a factor of 2. Calculation of the density of the cylindrical surface with the cube as reference volume shows that the surface density is decreased in $\mathrm{B}$. The shape factor, $\frac{\mathrm{S}^{3 / 2}}{\mathrm{~V}}$, on the other hand
remains constant

no means for obtaining the correct average of the compound geometric variable $\left[\frac{l}{\mathrm{~A}^{2}}\right]$. We can only estimate $\frac{\mathrm{L}}{(\overline{\mathrm{A}})^{2}}$, total capillary length (L) divided by average cross sectional area squared, and it is related to $\left[\frac{l}{\mathrm{~A}^{2}}\right]$ through the unknown topology of the vascular bed. If one accepts that a change in glomerular topology, for example the relation between parallel and serial capillaries, is not altered by the acutely induced diabetic state, then changes in $\frac{\mathrm{L}}{(\overline{\mathrm{A}})^{2}}$ do reflect changes in $\frac{\mathrm{p}}{\mathrm{v}}$ due to changes in parameters of capillary geometry. Under the additional assumption of isomorphous growth of glomeruli relative changes in $\frac{\mathrm{L}}{(\overline{\mathrm{A}})^{2}}$ are proportional to relative changes in $\frac{\mathrm{p}}{\mathrm{v}}$.

\section{Statistics}

All experimental results within the different groups of animals were searched for extreme values or outliers, tests being based on attributes of the sample itself [8]. Extreme values were checked for errors in measturements and calculations and if none were found all results from that animal were excluded.

Estimates of population parameters are given in terms of means $\pm \mathrm{CV}$ (Coefficient of Variation $=\frac{\mathrm{SD}}{\text { mean }}$ ) enabling immediate recognition of parameters with low variation, i.e. $\mathrm{CV}$ $\leq 0.1$ [9], which implies the combined virtue of precise methods and low biological variation. Parameter differences are given in terms of mean difference $\pm \mathrm{CE}$ (Coefficient of Error $=\frac{\text { SE of mean difference }}{\text { mean difference }}=\frac{1}{\text { Student's } t}$ ) enabling immediate recognition of differences which are unlikely to be due to chance alone, i.e. $\mathrm{CE} \leqslant 0.45$ implying statistical significance if the difference were the object of an a priori formulated null hypothesis. As stated in the introduction only one such was formulated in the present study: "there is no increase in the amount of 


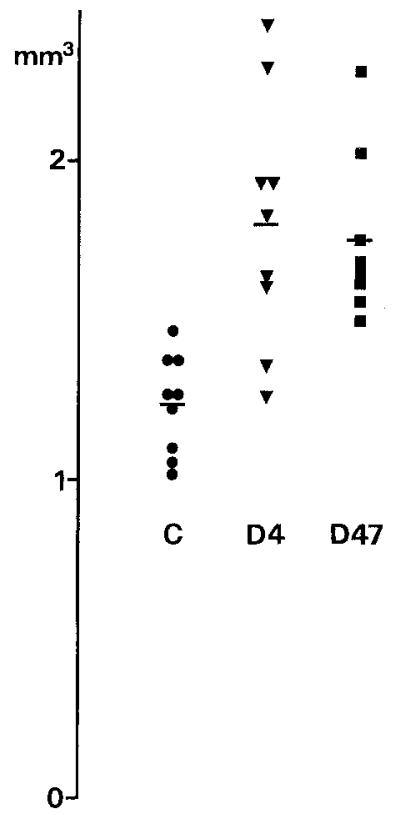

Fig. 4. The total volume of glomerular capillary peripheral basement membrane $\left(\mathrm{mm}^{3}\right)$ per left kidney in individual rats. C, D4 and D47 denote control, 4 day, and 47 day diabetic rats, respectively

glomerular capillary BM material very early in experimental diabetes'. Most of the differences in this paper are therefore given for descriptive purposes, and the coefficients of error are given in order to indicate that judged by their own attributes the differences described are not likely to be just haphazardous.

\section{Results}

Figure 4 shows the volume of peripheral BM in the experimental groups calculated as the product of surface area and arithmetic mean thickness, both of which are shown in Table 1 . The difference between mean volume in control rats $\left(1.2 \mathrm{~mm}^{3} \pm 0.13\right.$, mean $\pm \mathrm{CV})$ and $\mathrm{D} 4$ rats $\left(1.8 \mathrm{~mm}^{3} \pm 0.20\right)$ of $0.6 \mathrm{~mm}^{3} \pm$ 0.24 (mean difference $\pm \mathrm{CE}$ ) is statistically highly significant $(2 p=0.00073)$, judged by Student's $\mathrm{t}$-test. No further change in peripheral $\mathrm{BM}$ volume is seen in D47 rats $\left(1.8 \mathrm{~mm}^{3} \pm 0.15\right)$. This is, however, due to opposite changes in the two dimensions of membrane volume, surface area and thickness (see Table 1).

The link between the absolute glomerular volume determined by light microscopy [1] and the various relative morphometric parameters reported here at EM level is the tuft/polygon area fraction. This fraction is about $60 \%$ and it is very constant both within any of the experimental groups (CV from 1.8 to $6.5 \%)$ and between groups ( $\mathrm{CV}$ under $5 \%$ ).
The tuft volume was enlarged by $28 \%\left(8 \mathrm{~mm}^{3} \pm\right.$ 0.25 ) in D47 rats compared to controls, but $83 \%$ of this enlargement had taken place already at 4 days of diabetes, and there is no difference between D4 and D47 rats.

The volume fractions of the tuft constituents (peripheral basement membrane, capillary luminal space, endothelium, and mesangium) and epithelium and the basement membrane-like material (BMLM) in the mesangium did not show any variation between the experimental groups. The volume fractions are ranked in Table 2 according to their inter-individual variation in the control group. The volume fraction of BMLM shows a 9.0 -fold \pm 0.33 larger inter-individual relative variance among control animals than that of peripheral BM.

The absolute volumes of the different glomerular compartments showed varying changes in the diabetic animals (Table 2). The total volume of peripheral $\mathrm{BM}$, now calculated as $\mathrm{V}_{\mathrm{v}}$ (peripheral $\mathrm{BM}) \times \mathrm{V}($ Tuft $)$, was increased by $35 \%\left(0.5 \mathrm{~mm}^{3} \pm\right.$ 0.31 ) in $\mathrm{D} 4$ rats compared to controls and showed no further increase in D47 rats $\left(0.1 \mathrm{~mm}^{3} \pm 2.9\right)$. The less pronounced increase by $33 \%$ in BMLM was demonstrable in D47 rats only $\left(0.7 \mathrm{~mm}^{3} \pm 0.42\right)$.

The capillary space was enlarged by $27 \%\left(5 \mathrm{~mm}^{3}\right.$ $\pm 0.32)$ in D4 rats and there was only an insignificant further increase in $\mathrm{D} 47$ rats $\left(1 \mathrm{~mm}^{3} \pm 1.7\right)$. The endothelial volume only showed insignificant and inconsistent variations, whereas the capillary epithelial volume was enlarged by $30 \%\left(3 \mathrm{~mm}^{3} \pm 0.26\right)$ in D4 and showed no further change in D47 rats $\left(-1 \mathrm{~mm}^{3} \pm 1.2\right)$. Mesangial volume showed no enlargement even after 47 days of diabetes $\left(1.7 \mathrm{~mm}^{3}\right.$ $\pm 0.53)$.

The absolute surface of peripheral BM and of mesangium towards the urinary space was enlarged by 41 and $46 \%$ respectively in D4 rats (Table 1 ); accordingly the total filtration surface was enlarged by $51 \mathrm{~cm}^{2} \pm 0.16$. In D47 rats enlargements of 22 and $25 \%$ of the two surfaces remained (CE 0.32 and 0.38 respectively), but a decrease of the peripheral BM surface compared to D4 did show up $\left(-18 \mathrm{~cm}^{2}\right.$ $\pm 0.45)$. Comparison of shape factors $\left(\mathrm{S}^{3 / 2} / \mathrm{V}\right.$, Table 3 ) showed that at 4 days of diabetes both surfaces were enlarged considerably above that due to growth of the tuft (CE 0.16 and 0.31 respectively) whereas in D47 the absolute enlargements did not differ from those expected for a tuft of that volume (CE 1.5 for both).

Capillary luminal geometry changed markedly during the experimental period. In D4 rats the capillary space was elongated by $32 \%(199 \mathrm{~m} \pm 0.13)$, with an unchanged average cross sectional area $\left(-1 \mu \mathrm{m}^{2} \pm 2.3\right)$ whereas after 47 days of diabetes 
Table 1. Glomerular structures, absolute quantities per left kidney. $A_{A}(T u / P o l)$ is the areal fraction of tuft per polygon. $V(T u)$ is total volume of the glomerular tuft. $\mathrm{T}_{\mathrm{a}}$ is arithmetic mean thickness of the peripheral basement membrane. $\mathrm{S}(\mathrm{PBM})$ and $\mathrm{S}(\mathrm{Mes})$ are the surface areas of the peripheral basement membrane and mesangial resions, respectively. L(Cap) is total length of glomerular capillaries. $\overline{\mathrm{A}}(\mathrm{Cap})$ is average capillary cross sectional area. For each group are given the means $(\bar{C}, \bar{D} 4$ and $\bar{D} 47)$ and coefficients of variation $(\mathrm{CV})$ and for comparison of groups the differences of means and their coefficients of error $\left(\mathrm{CE}=\frac{1}{\text { Student's } t}\right)$

\begin{tabular}{|c|c|c|c|c|c|c|c|}
\hline & $\begin{array}{l}\mathrm{A}_{\mathrm{A}}(\mathrm{Tu} / \mathrm{Pol}) \\
\mathrm{mm}^{2} / \mathrm{mm}^{2}\end{array}$ & $\begin{array}{l}\mathrm{V}(\mathrm{Tu}) \\
\mathrm{mm}^{3}\end{array}$ & $\begin{array}{l}\mathrm{T}_{\mathrm{a}} \\
\mathrm{nm}\end{array}$ & $\begin{array}{l}\mathrm{S}(\mathrm{PBM}) \\
\mathrm{cm}^{2}\end{array}$ & $\begin{array}{l}\text { S(Mes) } \\
\mathrm{cm}^{2}\end{array}$ & $\begin{array}{l}\mathrm{L}(\text { Cap }) \\
\mathrm{m}\end{array}$ & $\begin{array}{l}\overline{\mathrm{A}}(\mathrm{Cap}) \\
\mu \mathrm{m}^{2}\end{array}$ \\
\hline Control rats & $\begin{array}{l}0.63 \\
0.60 \\
0.68 \\
0.65 \\
0.68 \\
0.71 \\
0.63 \\
0.67 \\
0.58\end{array}$ & $\begin{array}{l}26 \\
25 \\
34 \\
29 \\
28 \\
30 \\
28 \\
29 \\
27\end{array}$ & $\begin{array}{l}149 \\
163 \\
153 \\
136 \\
130 \\
134 \\
124 \\
130 \\
122\end{array}$ & $\begin{array}{r}92 \\
78 \\
96 \\
93 \\
81 \\
92 \\
82 \\
105 \\
90\end{array}$ & $\begin{array}{l}34 \\
32 \\
35 \\
31 \\
25 \\
27 \\
22 \\
31 \\
32\end{array}$ & $\begin{array}{l}621 \\
556 \\
712 \\
630 \\
538 \\
638 \\
609 \\
613 \\
619\end{array}$ & $\begin{array}{l}24 \\
28 \\
30 \\
22 \\
34 \\
29 \\
30 \\
28 \\
23\end{array}$ \\
\hline $\begin{array}{l}\text { Mean }(\overline{\mathrm{C}}) \\
\text { CV }\end{array}$ & $\begin{array}{l}0.65 \\
0.065\end{array}$ & $\stackrel{28}{0.10}$ & $\begin{array}{r}138 \\
0.10\end{array}$ & $\begin{array}{l}90 \\
0.095\end{array}$ & $\begin{array}{l}30 \\
0.15\end{array}$ & $\begin{array}{l}615 \\
0.081\end{array}$ & $\begin{array}{l}27 \\
0.14\end{array}$ \\
\hline $\begin{array}{l}\text { 4-day-diabetic } \\
\text { rats }\end{array}$ & $\begin{array}{l}0.60 \\
0.59 \\
0.63 \\
0.62 \\
0.55 \\
0.63 \\
0.66 \\
0.63 \\
0.66\end{array}$ & $\begin{array}{l}29 \\
35 \\
37 \\
36 \\
28 \\
30 \\
46 \\
37 \\
39\end{array}$ & $\begin{array}{l}121 \\
122 \\
161 \\
137 \\
124 \\
146 \\
165 \\
158 \\
139\end{array}$ & $\begin{array}{l}104 \\
134 \\
142 \\
133 \\
110 \\
110 \\
146 \\
122 \\
140\end{array}$ & $\begin{array}{l}26 \\
40 \\
48 \\
48 \\
43 \\
37 \\
52 \\
51 \\
45\end{array}$ & $\begin{array}{l}756 \\
896 \\
777 \\
876 \\
845 \\
744 \\
868 \\
752 \\
813\end{array}$ & $\begin{array}{l}26 \\
24 \\
29 \\
23 \\
18 \\
25 \\
32 \\
30 \\
32\end{array}$ \\
\hline $\begin{array}{l}\text { Mean }(\overline{\mathrm{D} 4}) \\
\mathrm{CV}\end{array}$ & $\begin{array}{l}0.62 \\
0.056\end{array}$ & $\begin{array}{l}35 \\
0.16\end{array}$ & $\begin{array}{r}141 \\
0.12\end{array}$ & $\begin{array}{l}127 \\
0.12\end{array}$ & $\begin{array}{l}43 \\
0.19\end{array}$ & $\begin{array}{l}814 \\
0.073\end{array}$ & $\begin{array}{l}27 \\
0.17\end{array}$ \\
\hline $\begin{array}{l}\text { 47-day-diabetic } \\
\text { rats }\end{array}$ & $\begin{array}{l}0.61 \\
0.64 \\
0.61 \\
0.61 \\
0.62 \\
0.60 \\
0.63 \\
0.62\end{array}$ & $\begin{array}{l}32 \\
34 \\
35 \\
33 \\
31 \\
40 \\
46 \\
42\end{array}$ & $\begin{array}{l}171 \\
151 \\
152 \\
156 \\
188 \\
143 \\
167 \\
166\end{array}$ & $\begin{array}{r}94 \\
103 \\
116 \\
96 \\
88 \\
118 \\
122 \\
138\end{array}$ & $\begin{array}{l}34 \\
26 \\
35 \\
36 \\
34 \\
40 \\
50 \\
42\end{array}$ & $\begin{array}{l}564 \\
628 \\
728 \\
536 \\
571 \\
600 \\
796 \\
825\end{array}$ & $\begin{array}{l}33 \\
33 \\
32 \\
35 \\
36 \\
40 \\
36 \\
31\end{array}$ \\
\hline $\begin{array}{l}\text { Mean }(\overline{\mathrm{D} 47}) \\
\mathrm{CV}\end{array}$ & $\begin{array}{l}0.62 \\
0.018\end{array}$ & $\begin{array}{l}37 \\
0.15\end{array}$ & $\begin{array}{l}162 \\
0.092\end{array}$ & $\begin{array}{l}109 \\
0.15\end{array}$ & $\begin{array}{l}37 \\
0.19\end{array}$ & $\begin{array}{l}656 \\
0.17\end{array}$ & $\begin{array}{l}35 \\
0.081\end{array}$ \\
\hline $\begin{array}{l}\overline{\mathrm{D} 4}-\overline{\mathrm{C}} \\
\mathrm{CE}\end{array}$ & $\begin{array}{r}-0.03 \\
0.62\end{array}$ & $\begin{array}{l}7 \\
0.32\end{array}$ & $\begin{array}{l}4 \\
2.1\end{array}$ & $\begin{array}{l}37 \\
0.16\end{array}$ & $\begin{array}{l}14 \\
0.23\end{array}$ & $\begin{array}{l}199 \\
0.13\end{array}$ & $\begin{array}{c}-1 \\
2.3\end{array}$ \\
\hline $\begin{array}{l}\overline{\mathrm{D} 47}-\overline{\mathrm{C}} \\
\mathrm{CE}\end{array}$ & $\begin{array}{r}-0.03 \\
0.45\end{array}$ & $\begin{array}{l}8 \\
0.25\end{array}$ & $\begin{array}{l}24 \\
0.29\end{array}$ & $\begin{array}{l}20 \\
0.32\end{array}$ & $\begin{array}{l}7 \\
0.38\end{array}$ & $\begin{array}{l}41 \\
1.0\end{array}$ & $\begin{array}{l}7 \\
0.23\end{array}$ \\
\hline $\begin{array}{l}\overline{\mathrm{D} 47}-\overline{\mathrm{D} 4} \\
\mathrm{CE}\end{array}$ & $\begin{array}{c}-0.00 \\
4.0\end{array}$ & $\begin{array}{l}1 \\
1.9\end{array}$ & $\begin{array}{l}20 \\
0.38\end{array}$ & $\begin{array}{l}-18 \\
0.45\end{array}$ & $\begin{array}{l}-6 \\
0.61\end{array}$ & $\begin{array}{r}-158 \\
0.27\end{array}$ & $\begin{array}{l}8 \\
0.23\end{array}$ \\
\hline
\end{tabular}

total capillary length was again normal (D47-C = $41 \mathrm{~m} \pm 1.0)$. However, the average luminal cross sectional area was now enlarged by $26 \%\left(7 \mu \mathrm{m}^{2} \pm 0.23\right.$, Table 1). Comparison of the shape factors $\mathrm{L}^{3}$ (Capillary)/V(Tuft) and $(\overline{\mathrm{A}})^{3 / 2}$ (Capillary)/V(Tuft) showed that at 4 days both structural quantities deviated in either direction from that expected from the enlarged tuft volume (Table 3), but in D47 rats they were within normal limits. The ratio $\frac{\mathrm{L}}{(\overline{\mathrm{A}})^{2}}$ (Capillary) of dimension length ${ }^{-3}$ was increased by $43 \%$ in D4 rats, but after 47 days of diabetes its diminution by $34 \%$ below normal compares well with the concomitant increase of $28 \%$ in tuft volume of dimension length ${ }^{3}$. 
Table 2. Glomerular volume fractions and absolute volumes per left kidney. The volume fractions $\left(\mathrm{V}_{\mathrm{V}}\right)$ are given with the tuft as reference space for the peripheral basement membrane (PBM), capillary luminal space (Cap), endothelial (En) and epithelial cell (Ep), total mesangial region (Mes), and basement membrane-like material (BMLM). V denotes total volume. For each group are given the means ( $\overline{\mathrm{C}}$, $\overline{\mathrm{D}} 4$ and $\overline{\mathrm{D}} 47)$ and coefficients of variation $(\mathrm{CV})$ and for comparison of groups the differences of means and their coefficients of error $\left(\mathrm{CE}=\frac{1}{\text { Student's } t}\right)$

\begin{tabular}{|c|c|c|c|c|c|c|}
\hline & $\begin{array}{l}\mathrm{V}_{\mathrm{V}}(\mathrm{PBM} / \mathrm{Tu}) \\
\mathrm{mm}^{3} / \mathrm{mm}^{3}\end{array}$ & $\begin{array}{l}\mathrm{V}_{\mathrm{V}}(\mathrm{Cap} / \mathrm{Tu}) \\
\mathrm{mm}^{3} / \mathrm{mm}^{3}\end{array}$ & $\begin{array}{l}\mathrm{V}_{\mathrm{V}}(\mathrm{En} / \mathrm{Tu}) \\
\mathrm{mm}^{3} / \mathrm{mm}^{3}\end{array}$ & $\begin{array}{l}\mathrm{V}_{\mathrm{v}}(\mathrm{Ep} / \mathrm{Tu}) \\
\mathrm{mm}^{3} / \mathrm{mm}^{3}\end{array}$ & $\begin{array}{l}\mathrm{V}_{\mathrm{V}}(\mathrm{Mes} / \mathrm{Tu}) \\
\mathrm{mm}^{3} / \mathrm{mm}^{3}\end{array}$ & $\begin{array}{l}\mathrm{V}_{\mathrm{V}}(\mathrm{BMLM} / \mathrm{Tu}) \\
\mathrm{mm}^{3} / \mathrm{mm}^{3}\end{array}$ \\
\hline Mean $(\overline{\mathrm{C}})$ & 0.049 & 0.60 & 0.12 & 0.35 & 0.24 & 0.074 \\
\hline $\mathrm{CV}$ & 0.081 & 0.092 & 0.12 & 0.17 & 0.18 & 0.25 \\
\hline Mean $(\overline{\mathrm{D} 4})$ & 0.054 & 0.61 & 0.11 & 0.38 & 0.22 & 0.074 \\
\hline $\mathrm{CV}$ & 0.19 & 0.073 & 0.18 & 0.18 & 0.20 & 0.25 \\
\hline Mean $(\overline{\mathrm{D} 47})$ & 0.054 & 0.62 & 0.10 & 0.34 & 0.23 & 0.078 \\
\hline $\mathrm{CV}$ & 0.24 & 0.064 & 0.21 & 0.16 & 0.17 & 0.16 \\
\hline$\overline{\mathrm{D} 4}-\overline{\mathrm{C}}$ & 0.005 & 0.02 & -0.01 & 0.03 & -0.01 & 0.000 \\
\hline $\mathrm{CE}$ & 0.74 & 1.3 & 0.76 & 1.1 & 1.7 & 24 \\
\hline$\overline{\mathrm{D} 47}-\overline{\mathrm{C}}$ & 0.005 & 0.02 & -0.02 & -0.01 & -0.01 & 0.004 \\
\hline $\mathrm{CE}$ & 0.95 & 1.0 & 0.48 & 2.1 & 2.5 & 2.1 \\
\hline \multirow{3}{*}{$\begin{array}{l}\overline{\mathrm{D} 47}-\overline{\mathrm{D} 4} \\
\mathrm{CE}\end{array}$} & 0.000 & 0.00 & -0.01 & -0.04 & 0.01 & 0.003 \\
\hline & 76 & 4.7 & 1.2 & 0.72 & 4.6 & 2.3 \\
\hline & $\begin{array}{l}\mathrm{V}(\mathrm{PBM}) \\
\mathrm{mm}^{3}\end{array}$ & $\begin{array}{l}\mathrm{V}(\mathrm{Cap}) \\
\mathrm{mm}^{3}\end{array}$ & $\begin{array}{l}\mathrm{V}(\mathrm{En}) \\
\mathrm{mm}^{3}\end{array}$ & $\begin{array}{l}V(E p) \\
\mathrm{mm}^{3}\end{array}$ & $\begin{array}{l}\mathrm{V} \text { (Mes) } \\
\mathrm{mm}^{3}\end{array}$ & $\begin{array}{l}\mathrm{V}(\mathrm{BMLM}) \\
\mathrm{mm}^{3}\end{array}$ \\
\hline Mean $(\overline{\mathrm{C}})$ & 1.4 & 17 & 3.4 & 10 & 6.7 & 2.1 \\
\hline $\mathrm{CV}$ & 0.091 & 0.13 & 0.16 & 0.18 & 0.21 & 0.31 \\
\hline Mean $(\overline{\mathrm{D} 4})$ & 1.9 & 22 & 3.8 & 13 & 7.8 & 2.6 \\
\hline $\mathrm{CV}$ & 0.23 & 0.17 & 0.21 & 0.11 & 0.27 & 0.30 \\
\hline Mean $(\overline{\mathrm{D} 47})$ & 1.9 & 23 & 3.7 & 12 & 8.3 & 2.8 \\
\hline $\mathrm{CV}$ & 0.19 & 0.15 & 0.25 & 0.18 & 0.26 & 0.19 \\
\hline$\overline{\mathrm{D} 4}-\overline{\mathrm{C}}$ & 0.5 & 5 & 0.4 & 3 & 1.1 & 0.5 \\
\hline $\mathrm{CE}$ & 0.31 & 0.32 & 0.80 & 0.26 & 0.75 & 0.68 \\
\hline$\overline{\mathrm{D} 47}-\overline{\mathrm{C}}$ & 0.6 & 6 & 0.3 & 2 & 1.7 & 0.7 \\
\hline $\mathrm{CE}$ & 0.26 & 0.25 & 1.3 & 0.44 & 0.53 & 0.42 \\
\hline$\overline{\mathrm{D} 47}-\overline{\mathrm{D} 4}$ & 0.1 & 1 & -0.1 & -1 & 0.5 & 0.2 \\
\hline $\mathrm{CE}$ & 2.9 & 1.7 & 3.3 & 1.2 & 2.0 & 1.6 \\
\hline
\end{tabular}

Table 3. Shape factors for surfaces and length, and the geometrical factor in Poiseuille's equation. V, $S$, and $L$ denote total volume, surface, and length, respectively, whereas $\overline{\mathrm{A}}$ is average cross sectional area. PBM and Mes are the interfaces between urinary space and peripheral basement membrane and mesangium, respectively. Cap denotes capillary luminal space. For each group are given the means $(\overline{\mathrm{C}}, \overline{\mathrm{D} 4}$ and $\overline{\mathrm{D} 47}$ ) and coefficients of variation (CV) and for comparison of groups the differences of means and their coefficients of error $\left(\mathrm{CE}=\frac{1}{\text { Student's } \mathrm{t}}\right)$

\begin{tabular}{|c|c|c|c|c|c|}
\hline & $\begin{array}{l}\frac{\mathrm{S}^{3 / 2}(\mathrm{PBM})}{\mathrm{V}(\mathrm{Tu})} \\
\mathrm{mm}^{3} / \mathrm{mm}^{3} \times 10^{-3}\end{array}$ & $\begin{array}{l}\frac{\mathrm{s}^{3 / 2}(\mathrm{Mes})}{\mathrm{V}(\mathrm{Tu})} \\
\mathrm{mm}^{3} / \mathrm{mm}^{3} \times 10^{-3}\end{array}$ & $\begin{array}{l}\frac{\mathrm{L}^{3}(\mathrm{Cap})}{\mathrm{V}(\mathrm{Tu})} \\
\mathrm{mm}^{3} / \mathrm{mm}^{3} \times 10^{-15}\end{array}$ & 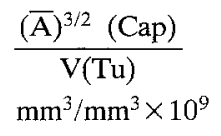 & $\begin{array}{l}\frac{\mathrm{L}}{(\overline{\mathrm{A}})^{2}} \text { (Cap) } \\
\mu \mathrm{m} / \mu \mathrm{m}^{4} \times 10^{-6}\end{array}$ \\
\hline $\begin{array}{l}\text { Mean }(\bar{C}) \\
C V\end{array}$ & $\begin{array}{l}30 \\
0.12\end{array}$ & $\begin{array}{l}5.8 \\
0.24\end{array}$ & $\begin{array}{l}8.3 \\
0.17\end{array}$ & $\begin{array}{l}5.1 \\
0.21\end{array}$ & $\begin{array}{l}0.83 \\
0.11\end{array}$ \\
\hline $\begin{array}{l}\text { Mean }(\overline{\mathrm{D} 4}) \\
\mathrm{CV}\end{array}$ & $\begin{array}{l}41 \\
0.081\end{array}$ & $\begin{array}{l}8.2 \\
0.21\end{array}$ & $\begin{array}{l}15.8 \\
0.23\end{array}$ & $\begin{array}{l}3.9 \\
0.18\end{array}$ & $\begin{array}{l}1.18 \\
0.16\end{array}$ \\
\hline $\begin{array}{l}\text { Mean }(\overline{\mathrm{D} 47}) \\
\mathrm{CV}\end{array}$ & $\begin{array}{l}31 \\
0.12\end{array}$ & $\begin{array}{l}6.2 \\
0.16\end{array}$ & $\begin{array}{l}8.1 \\
0.41\end{array}$ & $\begin{array}{l}5.7 \\
0.17\end{array}$ & $\begin{array}{l}0.54 \\
0.082\end{array}$ \\
\hline $\begin{array}{l}\overline{\mathrm{D} 4}-\overline{\mathrm{C}} \\
\mathrm{CE}\end{array}$ & $\begin{array}{l}11 \\
0.16\end{array}$ & $\begin{array}{l}2.4 \\
0.31\end{array}$ & $\begin{array}{l}7.5 \\
0.17\end{array}$ & $\begin{array}{l}-1.2 \\
0.36\end{array}$ & $\begin{array}{l}0.35 \\
0.48\end{array}$ \\
\hline $\begin{array}{l}\overline{\mathrm{D} 47}-\overline{\mathrm{C}} \\
\mathrm{CE}\end{array}$ & $\begin{array}{l}1 \\
1.5\end{array}$ & $\begin{array}{l}0.4 \\
1.5\end{array}$ & $\begin{array}{r}-0.2 \\
5.7\end{array}$ & $\begin{array}{l}0.6 \\
0.56\end{array}$ & $\begin{array}{r}-0.42 \\
0.35\end{array}$ \\
\hline $\begin{array}{l}\overline{\mathrm{D} 47}-\overline{\mathrm{D} 4} \\
\mathrm{CE}\end{array}$ & $\begin{array}{r}-10 \\
0.19\end{array}$ & $\begin{array}{l}-2.0 \\
0.36\end{array}$ & $\begin{array}{c}-7.7 \\
0.22\end{array}$ & $\begin{array}{l}1.7 \\
0.23\end{array}$ & $\begin{array}{r}-0.77 \\
0.21\end{array}$ \\
\hline
\end{tabular}




\section{Discussion}

Within 4 days of streptozotocin diabetes the glomeruli expand markedly and thereafter only small absolute volume changes are seen. The fast increases in many constituents are directionally non-uniform, giving rise to a pronounced anisomorphy at 4 days, but subsequent remodelling results in an isomorphous, enlarged glomerulus after $1^{1 / 2}$ months. These conclusions, based on comparisons between groups, are reached under the assumption that dimensional changes of the tissue during the preparative procedures are similar in the different groups. Under that assumption the magnitude of the shrinkage/swelling and its differential behaviour in different tissue components are of consequence only for the absolute value of the estimates - not for the direction of and the statistical confidence in the observed differences. Therefore, no effort was made to obtain measures of shrinkage/swelling in the present study.

The finding of significantly increased masses of peripheral BM and total glomerular BM in rats which have been hypoinsulinaemic and hyperglycaemic for less than 4 days indicates that a considerable acceleration of the basement membrane synthesis has taken place (assuming that the component which ultrastructurally and topologically is defined as BM is identical in the two situations). Even a total inhibition of basement membrane breakdown [10] would not lead to such changes. It is of considerable interest in this context that the amount of biochemically defined basement membrane protein per isolated glomerulus has been shown to be doubled in rats after 6 weeks of streptozotocin diabetes [11]. Furthermore, enzymes involved in the synthesis of basement membrane have been shown to be increased in experimental diabetes $[12,13]$.

A direct toxic effect of streptozotocin upon kidney morphology is ruled out by a number of facts. It is known that insulin treatment for 8 days to a very large extent prevents changes in both kidney weight and cell growth (protein/DNA ratio) [14] and that 6 months of insulin treatment prevents all morphological changes $[15,16,17]$. Moreover, in human diabetes all of the above morphological changes that have been looked for are present $[2,3]$. Obviously, the changes observed in D4 rats can not be part of a normal morphological development and as regards the period between D4 and D47 it is known that kidney and glomerular size and the glomerular ultrastructure do not change within one or two months in adult rats ([14], Gøtzsche, Gundersen \& Østerby, unpublished observations).

The rapidity with which these changes come about in the animal model does give support to the idea that similar changes may also develop rapidly in diabetic patients. A growth of the glomerular capillary surface which commences with the metabolic derangement therefore seems to be a morphological change that may reasonably explain the increase in glomerular filtration rate (GFR) found already at the diagnosis of the disease [18]. Recently, a very close correlation has been obtained between simultaneous estimates of GFR and of glomerular filtration surface in short-term diabetic patients [19]. The increased glomerular function in diabetic patients is known to be reversible upon strict insulin treatment [20].

Preliminary results suggest that after metabolic normalization for 4 weeks by islet transplantation the increase in filtration surface persists [21]. This finding suggests that the glomerular structure-function relationship is a complex one. It is now well recognized that flow, viscosity, permeability, pressure gradients, and capillary geometry play their roles in determining GFR, but quantitative information regarding their actual contributions is scarce. An illustration of the geometrical and topological complexity involved is given in a recent paper by Shea [22]. The rapid and marked changes of capillary geometry (viz. $\frac{\mathrm{L}}{(\overline{\mathrm{A}})^{2}}$ in Table 3 ) indicate the magnitude by which one might err by not considering this fundamental structural quantity in models assuming, for example, filtration equilibrium in the diabetic kidney.

It remains to be clarified whether the early glomerular growth, which in the animal model settles with a normal glomerular structural composition at an enlarged volume, has any long-term implications. At present it is not known whether it is linked in any way to the diabetic microangiopathy, i.e. basement membrane thickening. The two morphologically completely different modes of basement membrane accumulation might well have a common causative metabolic factor.

The present results have shown that the accumulation of basement membrane material can be triggered fast by the metabolic aberration of diabetes. Other studies [21, 23] indicate that the accumulation of basement membrane material is not reversible after metabolic normalization.

We may now envisage the course of development of the irreversible diabetic microangiopathy. During periods of poor metabolic control excess capillary basement membrane material is laid down, and when good control is achieved it is not removed again. The main practical consequence would be that great efforts should be made to maintain the best possible control in diabetic patients. 
Acknowledgements. We wish to express our thanks to K. Gerlach, B. Brøbeck, U.Dalsgård Hansen, and A. Meier for their very skilful technical assistance.

The study was supported by grants from: The Danish Medical Research Council, The Danish Diabetic Association, P.Carl Petersen Foundation, Nordic Insulin Foundation, Novo's Foundation, and Århus University.

\section{References}

1. Seyer-Hansen K, Hansen J, Gundersen HJG (1980) Renal hypertrophy in experimental diabetes: A morphometric study. Diabetologia 18: 501-505

2. Østerby R, Gundersen HJG (1975) Glomerular size and structure in diabetes mellitus. I. Early abnormalities. Diabetologia 11: $225-229$

3. Kroustrup JP, Gundersen HJG, Østerby R (1977) Glomerular size and structure in diabetes mellitus. III. Early enlargement of the capillary surface. Diabetologia 13: 207-210

4. Østerby R, Gundersen HJG (1978) Sampling problems in the kidney. In: Miles RE, Serra $\mathbf{J}$ (eds) Lecture notes in biomathematics, vol 23. Springer, Berlin Heidelberg New York, p 185-191

5. Weibel ER (1973) Stereological techniques for electron microscopic morphometry. In: Hayat MA (ed) Principles and techniques of electron microscopy, vol 3. van Nostrand Reinhold, New York, p 237-296

6. Jensen EB, Gundersen HJG, Østerby R (1979) Determination of membrane thickness distribution from orthogonal intercepts. J Microsc 115: 19-33

7. Weibel ER, Knight BW (1964) A morphometric study on the thickness of the pulmonary air-blood barrier. J Cell Biol 21: 367-384

8. Diem K, Lentner C (1970) Scientific tables, 7th ed. Geigy, Basel, p 171

9. Sargent F, Weinman KP (1966) Physiological individuality. In: Weyer EM (ed) The biology of human variation, Annals of the New York Academy of Sciences, vol 134. New York, p 696-719

10. Price RG, Spiro RG (1977) Studies on the metabolism of the renal glomerular basement membrane. J Biol Chem 252: $8597-8602$

11. Cohen MP, Klein CV (1979) Glomerulopathy in rats with streptozotocin diabetes. Accumulation of glomerular basement membrane analogous to human diabetic nephropathy. J Exp Med 149: 623-631
12. Spiro RG, Spiro MJ (1971) Effect of diabetes on the biosynthesis of the renal glomerular basement membrane: Studies on the glycosyltransferase. Diabetes 20: 641-648

13. Cohen MP, Khalifa A (1977) Effect of diabetes and insulin on rat renal glomerular protocollagen hydroxylase activities. Biochim Biophys Acta 496: 88-94

14. Seyer-Hansen K (1976) Renal hypertrophy in streptozotocindiabetic rats. Clin Sci Mol Med 51: 551-555

15. Rasch R (1979) Prevention of diabetic glomerulopathy in streptozotocin diabetic rats by insulin treatment: Kidney size and glomerular volume. Diabetologia 16: 125-128

16. Rasch R (1979) Prevention of diabetic glomerulopathy in streptozotocin diabetic rats by insulin treatment. Glomerular basement membrane thickness. Diabetologia 16: 319-324

17. Rasch R (1979) Prevention of diabetic glomerulopathy in streptozotocin diabetic rats by insulin treatment: The mesangial regions. Diabetologia 17: 243-248

18. Mogensen CE (1972) Kidney function and glomerular permeability to macromolecules in juvenile diabetes. Dan Med Bull 19 [Suppl 3]: 1-38

19. Hirose K, Østerby R (1979) A strong structure-function relationship between glomerular filtration rates and filtration surface areas in short-term diabetics (Abstract). In: Waldhäusl W, Alberti KGMM (eds) International Congress Series no 481. Excerpta Medica, Amsterdam, p 94

20. Mogensen CE (1975) Increased kidney size and glomerular filtration rate in untreated juvenile diabetes: Normalization by insulin-treatment. Diabetologia 11: 221-224

21. Gøtzsche O, Gundersen HJG, Østerby R (1979) Reversibility and non-reversibility of renal morphological changes in early experimental diabetes after pancreatic transplantation (Abstract). Acta Endocrinol [Suppl] (Kbh) 227: 27-28

22. Shea SM (1979) Glomerular hemodynamics and vascular structure. Microvase Res 18: 129-143

23. Steffes MW, Brown DM, Basgen JM, Matas AJ, Mauer SM (1979) Glomerular basement membrane thickness following islet transplantation in the rat. Lab Invest 41: 116-118

Received: April 5, 1979,

and in final revised form: January 8, 1980

R. Østerby

Institute of Anatomy

Århus University

DK-8000 Århus C

Denmark 